Available online on 15.11.2020 at http://jddtonline.info
Open Access to Pharmaceutical and Medical Research
und $2011-18$, publisher and licensee JDDT, This is an Open Access article which permits

Open 1 Access

Research Article

\title{
Evaluation of the Antioxidant Activity of Some Plants Used in the Management of Erectile Dysfunction by the BWA Community in Mali
}

\author{
Dembélé Jean ${ }^{1}$, Togola Issiaka1*, Daou Cheickna ${ }^{2}$, Diarra Nouhoum ${ }^{1}$, Konaré Mamadou A. ${ }^{1}$, Sanogo \\ Rokia $^{3}$ \\ ${ }^{1}$ Département de Biologie, Faculté des Sciences et Techniques (FST), Université des Sciences, des Techniques et des Technologies de Bamako \\ (USTTB), Bamako, Mali \\ 2 Département de Génie-Biologie, Institut des Sciences et Appliquées (ISA), Université des Sciences, des Techniques et des Technologies de \\ Bamako (USTTB), Bamako, Mali \\ ${ }^{3}$ Department des Sciences Pharmaceutiques et de Médicine Traditionnelle, Université des Sciences, des Techniques et des Technologies de \\ Bamako (USTTB), Bamako, Mali
}

\begin{abstract}
The erection has always symbolized strength and virile health. Erectile dysfunction is undoubtedly a concern as old as huma nity. Tamarindus indica L., Guiera senegalensis J.F.Gmel and Ximenia americana L. are commonly used in the traditional treatment of erectile dysfunction by the Bwa community in Mali. The aim of this study was to measure the total polyphenols and flavonoids and then to evaluate the antiradical activity of the extracts (aqueous and hydroalcoholic macerated and decocted) of the organs of these species. The study found that for all species, the hydro-alcoholic macerated extract showed the best results. The polyphenol contents have been $36.85 \pm 0.21 \mathrm{mgGAE} / \mathrm{g} ; 32.60 \pm 0.25 \mathrm{mgGAE} / \mathrm{g}$ and $29.79 \pm 0.51 \mathrm{mgGAE} / \mathrm{g}$ for Ximenia americana, Tamarindus indica and Guiera senegalensis respectively. The flavonoid contents have been $22.03 \pm 0.15 \mathrm{mgQE} / \mathrm{g} ; 17.53 \pm 0.02 \mathrm{mgQE} / \mathrm{g}$ and $8.03 \pm 0.03 \mathrm{mgQE} / \mathrm{g}$ for Ximenia americana, Tamarindus indica and Guiera senegalensis respectively. The antiradical activity expressed in $\mathrm{IC}_{50}$ is $37.54 \pm 0.75 \mu \mathrm{g} / \mathrm{mL} ; 52.75 \pm 0.71 \mu \mathrm{g} / \mathrm{mL}$ and $54.66 \pm 1.14 \mu \mathrm{g} / \mathrm{mL}$ for Ximenia americana Tamarindus indica and Guiera senegalensis respectively. This study revealed that those plants are rich in total polyphenols and show a good antiradical activity. This wealth would justify their traditional use. The biological tests would be necessary to confirm their use in the treatment of erectile dysfunction.
\end{abstract}

Keywords: Erectile dysfunction, polyphenols, antioxidant activity, Bwatun-Mali.

Article Info: Received 24 Aug 2020; $\quad$ Review Completed 18 Oct 2020; $\quad$ Accepted 27 Oct 2020; Available online 15 Nov 2020

口ition Cite this article as:

Dembélé J, Togola I, Daou C, Diarra N, Konaré MA, Sanogo R, Evaluation of the Antioxidant Activity of Some Plants Used in the Management of Erectile Dysfunction by the BWA Community in Mali, Journal of Drug Delivery and Therapeutics. 2020; 10(6):57-61 http://dx.doi.org/10.22270/jddt.v10i6.4559

*Address for Correspondence:

Togola Issiaka, Département de Biologie, Faculté des Sciences et Techniques (FST), Université des Sciences, des Techniques et des Technologies de Bamako (USTTB), Bamako, Mali

\section{INTRODUCTION}

Originally, nature was made up of plant life and used as food for animals feeding and humans' nutriment. However, in addition to this nutritional role, peoples discovered several other functions that plants could provide, such as the healing power of plants. In Africa the healing power of plants has been known since ancient times. Erectile dysfunction is defined as "a persistent or recurrent disability of a man to achieve or maintain a sufficient erection of the penis for sexual activity" 1 . Psychological and physiological factors and certain classes of drugs induce the production of a large quantity of free radicals that cause oxidative stress, resulting in a decrease in sexual performance 2, 3,4,5. To alleviate these disorders numerous treatments using synthetic molecules, such as type 5 phosphodiesterase inhibitors, are currently proposed 6 . However, the high cost of these products, as well as the secondary effects they induce, give new impetus to natural substances in plants that are reputed to be aphrodisiacs $7,8,9$. Studies have shown that many secondary metabolites such as alkaloids, tannins, terpenes, saponins and flavonoids have aphrodisiac effects 10,11,12. Some erectile disorders have a vascular origin due to the diseases such as diabete and hypertension or stress related origin 4,2 . The action of anti-hypertensive and anti-diabetic compounds 
such as tannins, saponosides and flavonoids could be taken into account in the restoration of the erection if the cause is eliminated ${ }^{13}$. Many compounds such as the polyphenols are powerful antioxidants that can help to reduce the effect of oxidative stress. The Bwa community in Mali are living in the area called the Bwatun, located in south-eastern Mali. In this area the local population makes extensive use of medicinal plants, and gender issues remain a taboo ${ }^{9}$. An ethnobotanical survey conducted by 9 revealed that the species Tamarindus indica, Guiera senegalensis and Ximenia americana are commonly used in the traditional treatment of erectile dysfunction in the Bwatun area. They also showed that these plants are very rich in secondary metabolites. Polyphenols are natural compounds that are widespread in the plant kingdom and are becoming increasingly important, particularly due to their beneficial effects on virile health. In this context, the present study set itself the objective of measuring total polyphenols and flavonoids and then evaluating the antiradical activity of extracts of these three plants (Tamarindus indica, Guiera senegalensis and Ximenia americana).

\section{MATERIAL AND METHODS}

\section{Plant Materials}

The plant material consisted of roots of Tamarindus indica "So'o" and Guiera senegalensis "Suncawe" and the stem bark of Ximenia Americana "Cocognanwe" The samples were collected in the village of Mandiakuy (Bwatun area) in September 2018. These plants were identified at the Laboratory of Tropical Ecology of the Faculty of Science and Technology. They were dried at room temperature $\left(30-35^{\circ}\right.$ C) and then reduced to powder. The powders obtained from these organs were used for experimental studies.

\section{Preparation of Extracts}

We carried out an extraction on $5 \mathrm{~g}$ of the plant material with $50 \mathrm{~mL}$ of $80 \%$ methanol $(\mathrm{MeOH})$ for 20 minutes at room temperature $\left(30-35^{\circ} \mathrm{C}\right)$, then filtered and recovered the supernatant. We evaporated dry under vacuum with the Rotavapor at a temperature of $45^{\circ} \mathrm{C}$. We dissolved the residue in $50 \mathrm{~mL}$ of $50 \%$ methanol and kept it cold for analysis according to the modified protocol described by 14 .

\section{Dosage of Total Polyphenols}

Polyphenols were determined by spectrophotometric method using the Folin-Ciocalteu reagent according to the protocol of 15 , slightly modified by 16 . Briefly, $500 \mu \mathrm{L}$ of FolinCiocalteu reagent (diluted $10 \%$ in distilled water) was added to $100 \mu \mathrm{L}$ of extract with well determined concentrations. Four (4) minutes later, $400 \mu \mathrm{L}$ of Sodium Carbonate $\left(\mathrm{Na}_{2} \mathrm{CO}_{3}\right)$ at $75 \mathrm{mg} / \mathrm{g}$ are added to the reaction mixture. After a 2 hour incubation at room temperature and protected from light, the absorbance is read at $765 \mathrm{~nm}$. The calibration line is performed with gallic acid of concentration $(0.8 ; 1.6 ; 2.4 ; 3.2$; $4 \mu \mathrm{g} / \mathrm{mL}$ ) following the same assay steps. The concentrations of the phenolic compound are established from the regression line of the calibration curve. The results are expressed in milligram equivalent of gallic acid per gram of extract (mg GAE/g). All manipulations are repeated 3 times.

\section{Dosage of Total Flavonoids}

Flavonoids were determined by spectrophotometric method using aluminium trichloride reagent $\left(\mathrm{AlCl}_{3}\right)$ according to the protocol described by ${ }^{17}$. To $1 \mathrm{~mL}$ of extract, we added $1 \mathrm{~mL}$ of the $\mathrm{AlCl}_{3}$ solution (2\% in methanol). After $10 \mathrm{~min}$ incubation, at room temperature and protected from light, the absorbances were measured by a spectrophotometer at
$430 \mathrm{~nm}$. All the manipulations are repeated 3 times. Under the same conditions, a calibration range is carried out with quercetin $(5 ; 10 ; 20 ; 40 ; 80 \mu \mathrm{g} / \mathrm{mL})$ following the same dosing steps. The quantity of flavonoids is determined from the regression line of the calibration lines. The results are expressed in milligram quercetin equivalent per gram of extract (mg QE/g).

\section{Antioxidant Activity}

\section{Characterisation of Antioxidant Activity by Thin Layer Chromatography (TLC)}

Antioxidant activity was characterised by TLC using the DPPH reagent (2,2-DiPhenyl-1-Picryl-Hydrazyl) according to the protocol described by ${ }^{18}$. The system was composed of Butanol - Acetic Acid - Water (BAW) in the proportions (7: 1 : $2 \mathrm{v} / \mathrm{v} / \mathrm{v})$. Ten microliters $(10 \mu \mathrm{l})$ were deposited as a dot 1 $\mathrm{cm}$ apart and located approximately $1 \mathrm{~cm}$ from the bottom of the G60F254 $0.2 \mathrm{~mm}$ silica plate. The antioxidant activity of the plants is characterised by the appearance of yellow stripes on a purple background on the TLC plate after revelation by the $0.024 \%$ DPPH solution.

\section{Evaluation of Antioxidant Activity by the DPPH method}

The DPPH (2, 2-diphenyl-1-picryl-hydrazyl) test according to the method used by ${ }^{19}$ with slightly modified was used to evaluate the antioxidant activity of our extracts. $50 \mu \mathrm{L}$ of each extract solution to be tested with different concentrations $(12.5 ; 26 ; 40 ; 60 ; 80 \mu \mathrm{g} / \mathrm{mL})$ are added to $1.95 \mathrm{~mL}$ of the methanolic solution of DPPH $(0.024 \mathrm{~g} / \mathrm{L})$. At the same time, a negative control is prepared by mixing 50 $\mu \mathrm{L}$ of methanol with $1.95 \mathrm{~mL}$ of the methanolic DPPH solution. The absorbance reading was taken against a blank at $517 \mathrm{~nm}$ after $30 \mathrm{~min}$ incubation in the dark and at room temperature. The positive control is represented by a solution of a standard antioxidant, ascorbic acid, whose absorbance was measured under the same conditions as the extracts and for each concentration the test was repeated 3 times. The antioxidant activity related to the scavenging effect of the DPPH radical is expressed as percentage inhibition (PI) calculated from absorbances obtained according to the following formula:

$$
[\mathrm{PI}]=\left(\mathrm{A}_{0}-\mathrm{A}_{1}\right) / \mathrm{A}_{0} \times 100
$$

$\mathrm{A}_{0}=$ DPPH absorbance; $\mathrm{A}_{1}$ : sample absorbance.

The IC50 (concentrations that inhibit $50 \%$ of the DPPH radical) were deduced from the linear regression line obtained from the graph of the percentage inhibition of DPPH

\section{Data Analysis}

Data processing was done using Excel@ version 2013 and Minitab 18.1 software. Analyses were run in triplicates and the results were expressed as mean values with standard error mean.. The single-factor ANOVA test using the Fisher test was chosen to compare the polyphenol and flavonoid contents and the antioxidant activity of different types of extracts. P-values less than 0.05 were considered statistically significant.

\section{RESULTS}

\section{Total Polyphenol and Flavonoid Contents}

The contents of total polyphenols and flavonoids are summarised in the Table 1. 
Table 1: Summary of total polyphenol and flavonoid contents

\begin{tabular}{llcc}
\hline Plants & Extract types & $\begin{array}{c}\text { Total Phenols } \\
\text { (mgGAE/g) }\end{array}$ & $\begin{array}{c}\text { Flavonoids } \\
\text { (mgQE/g) }\end{array}$ \\
\hline Ximenia & AM & $35,34 \pm 0,57^{\mathrm{B}}$ & $20,0 \pm 0,26^{\mathrm{B}}$ \\
americana L. & Dec & $34,10 \pm 0,34^{\mathrm{C}}$ & $19,7 \pm 0,08^{\mathrm{C}}$ \\
\hline \multirow{2}{*}{ Tamarindus } & HAM & $36,85 \pm 0,21^{\mathrm{A}}$ & $22,03 \pm 0,15^{\mathrm{A}}$ \\
indica L. & AM & $24,42 \pm 0,28^{\mathrm{G}}$ & $12,23 \pm 0,06^{\mathrm{E}}$ \\
\hline Guiera & Hec & $28,70 \pm 0,41^{\mathrm{F}}$ & $11,17 \pm 0,05^{\mathrm{F}}$ \\
Senegalensis & AM & $32,60 \pm 0,25^{\mathrm{D}}$ & $17,53 \pm 0,02^{\mathrm{D}}$ \\
J F G. & Dec & $22,68 \pm 0,28^{\mathrm{H}}$ & $4,77 \pm 0,05^{\mathrm{I}}$ \\
\hline
\end{tabular}

*Mean values $( \pm$ SE) in column with different letters are significantly different $(\mathrm{p}<0.05)$

Legend: AM: Aqueous Maceration. Dec: Decoction. HAM: Hydroalcoholic Maceration.

All the polyphenol (mgGAE/g) and the flavonoid (mgQE/g) contents differ from one solvent to another $(\mathrm{p}<0.05)$ and from one plant to another $(\mathrm{p}<0.05)$. The highest contents of polyphenols $(36.85 \pm 0.21 \mathrm{mgGAE} / \mathrm{g})$ and flavonoids $(22.03 \pm 0.15 \mathrm{mgQE} / \mathrm{g})$ were obtained with hydroalcoholic extracts of Ximenia americana. The hydro-alcoholic extract has shown the best results in all plants. Ximenia americana has presented the highest levels of polyphenols $(36.85 \pm 0.21$ mgGAE/g) followed by Tamarindus indica $(32.60 \pm 0.25$ mgGAE/g) and Guiera senegalensis (29.79 $\pm 0.51 \mathrm{mgEAG} / \mathrm{g})$. Ximenia americana had the highest levels of flavonoids
$(22.03 \pm 0.15 \mathrm{mgQE} / \mathrm{g})$ followed by Tamarindus indica $(17.53 \pm 0.02 \mathrm{mgQE} / \mathrm{g})$ and Guiera senegalensis $(8.03 \pm 0.03$ $\mathrm{mgQE} / \mathrm{g}$ ).

\section{Antioxidant Activity}

Characterisation of Antioxidant Activity by Thin Layer Chromatography (TLC)

The Figure 1 shows the chromatogram of the antioxidant activity of extracts of Tamarindus indica, Guiera senegalensis and Ximenia americana.

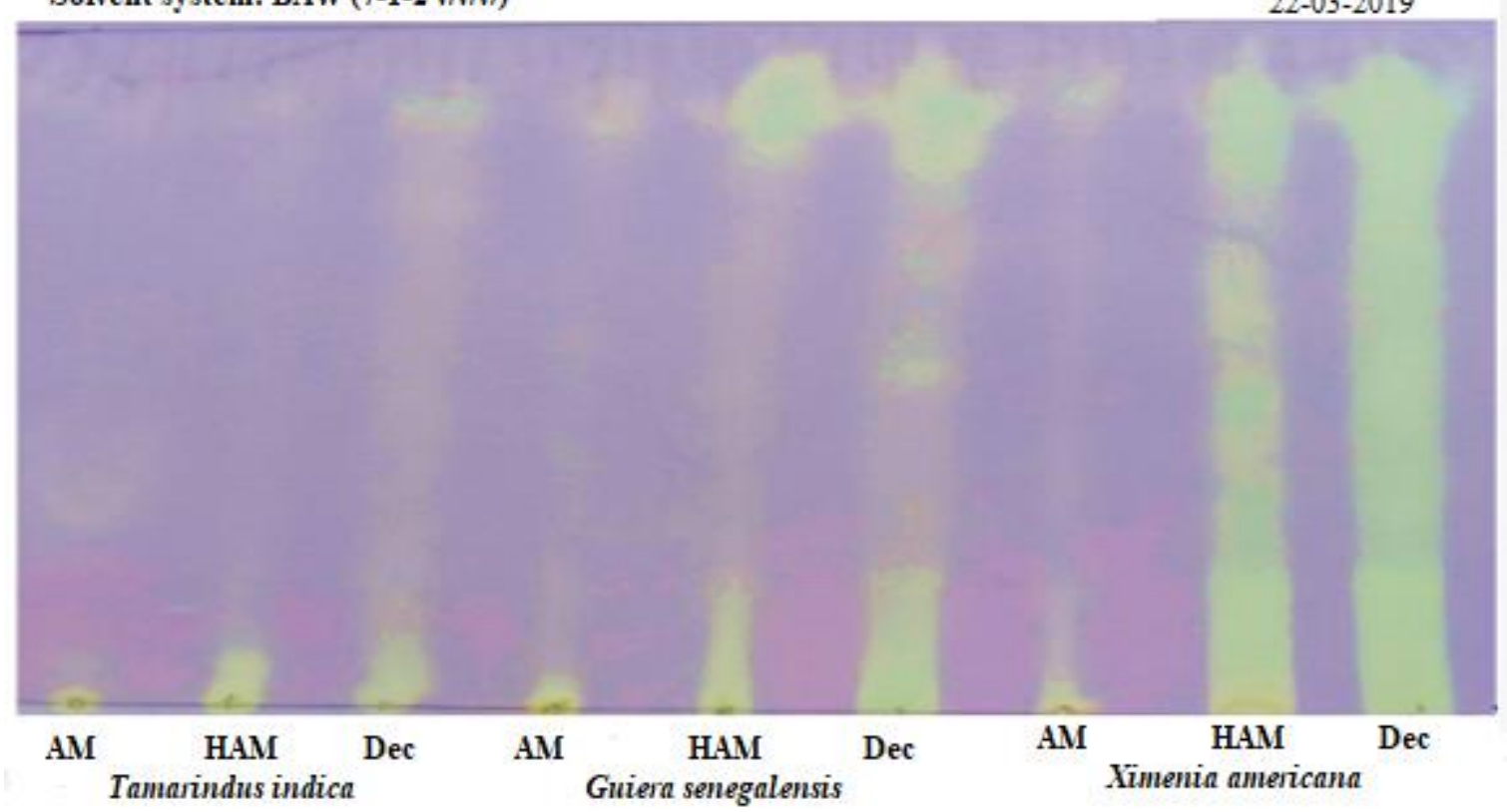

Legend: AM: Aqueous Maceration. HAM: Hydroalcoholic Maceration. Dec: Decoction.

Figure 1: Chromatogram of the different extracts revealed to the DPPH

The yellow stains have been observed with all the extracts and on all the plants, indicating the antiradical activity. The yellow spots observed with Ximenia americana are much more remarkable. 
Evaluation of antioxidant activity by the DPPH method

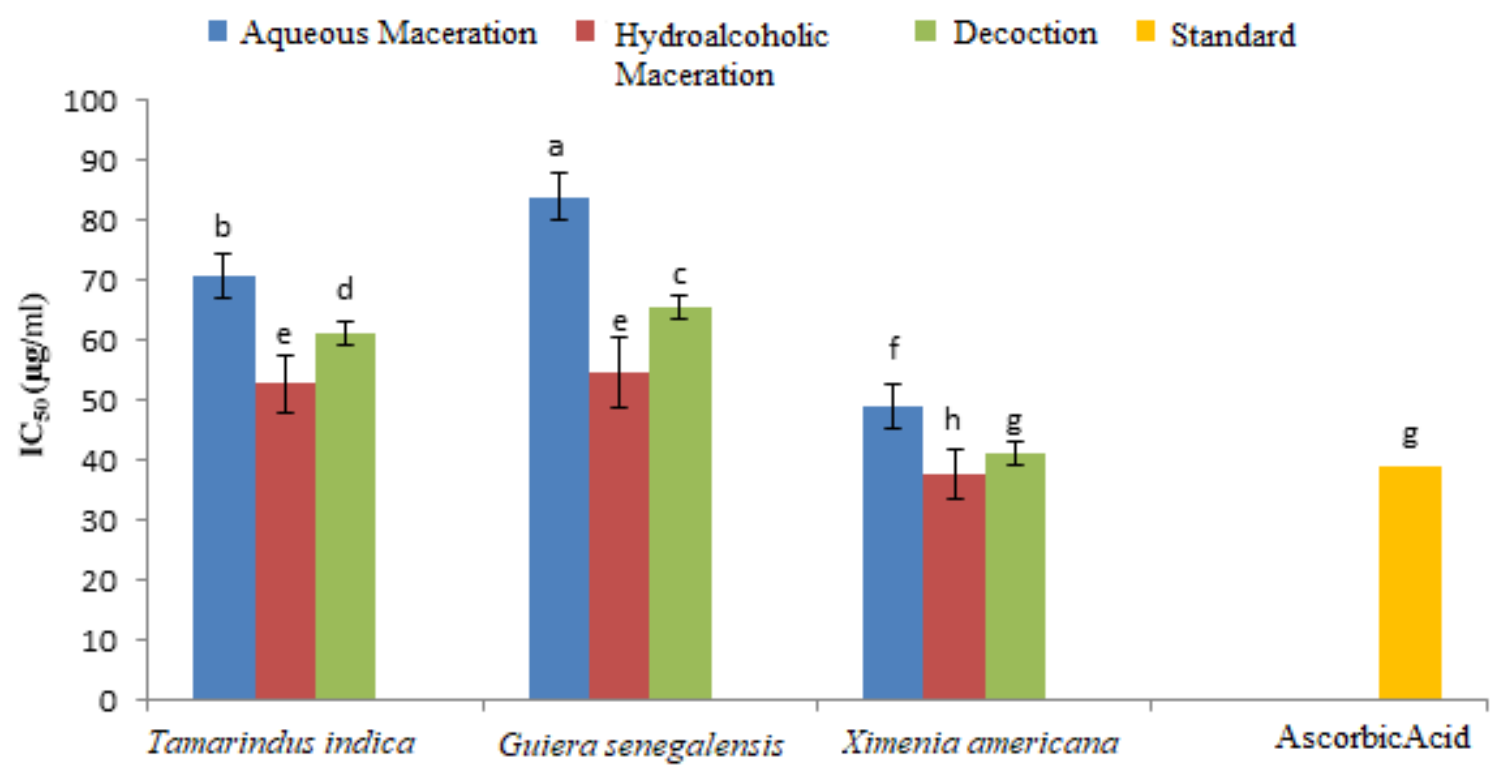

Figure 2: Variation of $\mathrm{IC}_{50}$ by extracts and plant

The Figure 2 summarises the antioxidant activity of the extracts of the three plants studied and this activity is expressed in $\mathrm{IC}_{50}$. Analysis of these data showed that the antioxidant power varies according to the solvent $(\mathrm{p}=0.4 .10$ 16) and and the species $\left(\mathrm{p}=0.35 .10^{-15}\right)$.

Extracts of Ximenia americana have an antiradical activity similar to that of ascorbic acid. Methanolic extracts were found to be more active than the other two types of extracts.

\section{DISCUSSION}

Ximenia Americana had the highest polyphenol content $(36.85 \pm 0.21 \mathrm{mgGAE} / \mathrm{g})$ followed by Tamarindus indica $(32.60 \pm 0.25 \mathrm{mgGAE} / \mathrm{g})$ and Guiera senegalensis $(29.79 \pm 0.51$ mgGAE/g). The results obtained in this study with the stem bark of Ximenia americana are lower than those obtained with its leaves, $43.10 \mathrm{mgGAE} / \mathrm{mL} 20$. The data found with Tamarindus indica are in agreement with those of 21 which were $30.4 \pm 2.6 \mathrm{mg} / \mathrm{g}$ with the hexanic extract of the stem bark. 22 reached $58 \mathrm{mgEAG} / \mathrm{g}$ with the ethanolic extract of the leaves of Guiera senegalensis, which is higher than ours. As for the flavonoids, Ximenia americana has exhibited the highest content with $(22.03 \pm 0.15 \mathrm{mgQE} / \mathrm{g})$ This content is higher than that obtained by ${ }^{23}$ with the butanolic extract of the leaves, i.e. $10.02 \%$. With Tamarindus indica, we attained $17.53 \pm 0.02 \mathrm{mgQE} / \mathrm{g}$, a value higher than that found with the hydroethanolic extract of the fruits, which was $8.3 \mathrm{mg} / \mathrm{g} 24$. In 2013, 22 obtained $36 \mathrm{mgQE} / \mathrm{g}$ with the ethanolic extract from the leaves of Guiera senegalensis, which is higher than ours $(8.03 \pm 0.03 \mathrm{mgQE} / \mathrm{g})$. Hydroalcoholic extracts showed the highest antioxidant activity with $\mathrm{IC}_{50} \mathrm{~S}$ of $37.54 \pm 0.75$ $\mu \mathrm{g} / \mathrm{mL} ; \quad 52.75 \pm 0.71 \mu \mathrm{g} / \mathrm{mL}$ and $54.66 \pm 1.14 \mu \mathrm{g} / \mathrm{mL}$ respectively for Ximenia americana; Tamarindus indica and Guiera senegalensis. The antioxidant power of Ximenia americana is higher than that obtained by ${ }^{20}$ which was 2.78 $\mu \mathrm{g} / \mathrm{ml}$ with the methanolic extract of the leaves and lower than that obtained by 25 which was $82.5 \pm 3.60 \mu \mathrm{g} / \mathrm{ml}$ with the methanolic extract of the trunk bark. The antiradical power obtained by 24 was $15 \mathrm{mg} / \mathrm{ml}$ with the hydroethanolic extract of the pulp of the fruit of Tamarindus indica and is higher than ours. Our results are higher than those obtained by 25 which were $39.12 \pm 4.1 \mu \mathrm{g} / \mathrm{mL}$ with the methanolic extract of the leaves of Guiera senegalensis. The polyphenol compounds have a role as natural antioxidants that is attracting increasing interest in the prevention and treatment of inflammatory and cardiovascular diseases ${ }^{26}$ (Talbi et al., 2015). An ethnobotanical survey conducted by 9 revealed that the species of Tamarindus indica, Guiera senegalensis and Ximenia americana are commonly used in the traditional treatment of erectile dysfunction at Bwatun area in Mali. They also showed that these plants are very rich in secondary metabolites. Many studies have shown that the flavonoids have the antioxidant properties and are reported to raise androgen levels in animals; they may also contribute to the observed aphrodisiac effect 27. The saponins stimulate testosterone and sperm production 28 . The tannins are used to treat and cure haemorrhoids, which are the main cause of sexual dysfunction ${ }^{11}$. This study found that those plants are rich in total polyphenols and have good anti-free radical activity. These polyphenols could help reduce the effect of oxidative stress and restore erection.

\section{CONCLUSION}

The present study shows that the root extracts of Tamarindus indica and Guiera senegalensis and the stem bark extracts of Ximenia americana are rich in total polyphenols and present a good antiradical activity. This richness would justify the use of these plants in the traditional treatment of erectile dysfunction by the traditional practitioners. In the hypothesis that the roots and stem bark of the plants could be replaced by its leaves, to better preserve biodiversity, the investigations should then be carried out to compare their phytochemical compositions and their biological activities. The biological tests would also be necessary to confirm their use in the treatment of erectile dysfunction.

\section{CONFLICTS OF INTERESTS:}

The authors have not declared any conflicts of interests.

\section{REFERENCES}

1. Sharma M., Arya D., Bhagour K., and Gupta R. S. Natural aphrodisiac and fertility enhancement measures in males. A review. Current Medicine Research and Practice 2017; 7:51-58.

2. Bivalacqua TJ, Usta MF, Kendirci M. and Pradhan L. Superoxide anion production in the rat penis impairs erectile function in diabetes: influence of in vivo extracellular superoxide dismutase 
gene therapy. The Journal of Sexual medicine, 2005; 2(2):187198.

3. Esper R J, Nordaby RA, Vilarino J O, Paragano A, Cacharron J L. and Machado R. Endothelial dysfunction: a comprehensive appraisal. Cardiovasc Diabetol, 2006; 5(1):4.

4. Kuhn J. M. Hypogonadisme et dysfonction érectile. Act méd Int. 2001; 5(6):256- 262.

5. Hafez E. S and Hafez S. D. 2005. Erectile dysfunction: anatomical parameters, etiology, diagnosis, and therapy. Archives of Andrology, 51: 15-31.

6. Lue T. F. Erectile dysfunction. The New England Journal of Medecine, 2000; 342:1802-1813.

7. Carpentier M., Sahpaz S. et Bailleul F.: Plantes et dysfonction $\begin{array}{lll}\text { érectile. } & \text { Phytothérapie. 2(3):66-71. }\end{array}$ https://doi.org/10.1007/s10298-004-0024-3.

8. Morabandza C.J., Ondele R., Elion Itou R.D.G., Etou Ossibi A.W., Imbiella C., Mokondjimobe E., Ongoka P. R. and Abena A. A. Aphrodisiac activity of aqueous and hydro ethanolic extracts of the stem bark of strychnos camptoneura (longaniaceae) in wistar rat. Asian Journal of Science and Technology, 2017; 08(10):6055-6059.

9. Togola I, Dembélé J, Daou C, Dénou A, Diarra N, Badiaga M, Konare MA, Karembé M, Sanogo R. Ethnobotanical Survey and Phytochemical Screening of Some Plants used in the Management of Erectile Dysfunction in Bwatun (Mali). Journal of Natural Product and Plant Resources, 2020; 9(1):1-8.

10. Drewes SE, Georges J. and Khan F. R. Recent findings on natural products with erectile dysfunction activity. Phytochemistry, 2003; 62:1019-1025.

11. Andzouana M. and Mombouli J.B. Assessment of the Chemical and Phytochemical Constituents of the Leaves of a Wild Vegetable Ochthocharis dicellandroides (Gilg). 2012.

12. Boua B. B., Mamyrbekova-Bekro J. A., Kouamé B. A., Bekro Y. A Criblage phytochimique et potentiel érectile de Turraea heterophylla de Côte d'Ivoire. Journal of Applied Biosciences 2013; 68:5394-5403.

13. Dey L.M., Anoja S., Attele D. and Chun-Sun Y.M. 2002. Alternative therapy for type 2 diabetes. Alternative Medecine Review 2002; $7(1): 45-58$.

14. Keïta JN, Traore N, Diarra N, Koné D, Mariko B, Pelcouliba D. and Poisson JF. Isolation and Identification of Nicotiflorin from the Leaves of Costus spectabilis (Fenzl) K. Schum. Der Chemica Sinica 2019; 10(1):782-787.

15. Singleton, V. L.; Orthofer, R.; Lamuela-Raventos, R. M. Analysis of total phenols and other oxidation substrates and antioxidants by means of Folin-Ciocalteu Reagent. Methods Enzymol. 1999; 299:152-178.

16. Togola I, Dembélé AA, Tounkara F, Diarra N, Konaré MA, Karembé M, Maiga SZ, Dembélé D. Evaluation of in vitro Antioxidant Activities of Ethanol Extracts of Datura innoxia Mill. Leaves and Seeds Harvested in Mali. Annual Research and Review in Biology 2019; 33(2):1-8.
17. Chang C, Yang M, Wen H, Chern J. 2002. Estimation of total flavonoids content in propolis by two complementary colorimetric methods. J Food Drug Analysis. 10: 178-182.

18. Traoré K., Haidara M., Dénou A., Kanadjigui F., Sogoba M.N., Diarra B., Maïga S. et Sanogo R. Criblage phytochimique et activités biologiques de quatre plantes utilisées au Mali dans la prise en charge du paludisme chez les enfants. European Scientific Journal, 2019; 15(6):212-226.

19. Brand Williams W, Cuvelier ME, Berset C. Use of free radical method to evaluate anti-oxidant activity. Lebensmittel Wissenschaft and Technologie. 1995; 28(1):25-30.

20. Mariko M., Sarr S.O., Diop A., Modi I. A., Dackouo B., Diop Y. M. Antioxidant activity study and total phenolic determination of leaf extracts of Ximenia americana L. (Olacaceae) an antitumor plant used traditionally in Mali. Journal of Applied Biosciences, 2016; 106:10258-10265.

21. Nurhanani R., Sarni M. J., Amirah F. A. M., Senthilkumar S., Azlina A. A. 2012. Effects of various solvents on the extraction of antioxidant phenolics from the leaves, seeds, veins and skins of Tamarindus indica L. Food Chemistry 2012; 131:441-448.

22. Abubakr M, Sirag N, Osman I, Osman M, Abakar S and AboulEnein AM. Anticancer and antioxidant activities of Guiera senegalensis. Sudan JMS 2013; 8(3).

23. Kabran G. R. M., Ambeu N. C., Mamyrbékova-Békro J. A. ; Békro Y. A. Phenols et flavonoïdes totaux dans les extraits organiques de dix Plantes utilisées dans la traditherapie du cancer du sein en Côte d'Ivoire. European Journal of Scientific Research, 2012; 68(2):182-190.

24. Ahodegnon D. K., Gnansounou M., Bogninou R. G. S., Kanfon E. R., Chabi B et al., Biochemical profile and antioxidant activity of Parkia biglobosa and Tamarindus indica fruits acclimated in Benin. Int. J. Adv. R es. 2018; 6(11):702-711.

25. Maikai, V. A., Kobo, P. I. and Maikai, B. V. O. Antioxidant properties of Ximenia Americana. African Journal of Biotechnology, 2010; 9(45):7744-7746.

26. Kouamé, J. C. G., Palé E., Bassolé H., Guissou I. P., Simporé J., Nikiéma J. B. Etude des propriétés cytotoxiques et antiradicalaires d'extraits de feuilles et de galles de Guiera senegalensis J. F. Gmel (Combretacae). Science et technique, Sciences de la santé, 2009.

27. Talbi H., Boumaza A., Karym. E. M., Talbi J., Hilali A. Evaluation de l'activité antioxydante et la composition physico-chimique des extraits méthanolique et aqueux de la Nigella sativa L. Journal of Materials and Environmental Science 2015; 6(4):11111117.

28. Saleem A., Ahotupa M. and Pihlaja K. Total phenolics concentration and antioxidant properties of extracts of medicinal plants of Pakistan. Zeitschrift Naturforschung 2001; 56(11-12):973-978.

29. Gauthaman K. and Adaikan P. The hormonal effects of Tribulus terrestris and its role in the management of male erectile dysfunction: an evaluation using primates, rabbit and rat, $\begin{array}{lll}\text { Phytomedicine, 2008; } & \text { 15(1-2):44-54. }\end{array}$ 10.1016/j.phymed.2007.11.011. 